\title{
Platform design for monitoring the quality of electrical energy
}

\section{Diseño de plataforma para monitoreo de calidad de la energía eléctrica}

TURIJÁN-ALTAMIRANO, Salomón Noé†*, MUÑOZ-HERNÁNDEZ, Germán Ardul, CHÁVEZCANO, Omar and RODRÍGUEZ-GONZÁLEZ, Julio

\section{Tecnológico Nacional de México / Instituto Tecnológico de Puebla}

ID $1^{\text {st }}$ Author: Salomón Noé, Turiján-Altamirano / ORC ID: 0000-0003-3790-7055, CVU CONACYT ID: 377682

ID $1^{\text {st }}$ Coauthor: Germán Adul, Muñoz-Hernández / ORC ID: 0000-0003-4861-0345, CVU CONACYT ID: 122490

ID $2^{\text {nd }}$ Coauthor: Omar, Chávez-Cano / ORC ID: 0000-0002-1883-1932, CVU CONACYT ID: 857314

ID $3^{\text {st }}$ Coauthor: Julio, Rodríguez-González / ORC ID: 0000-0003-0515-778X, CVU CONACYT ID: 78003

\begin{abstract}
The present work shows the development of a platform, based on an embedded system, for the monitoring of disturbances present in the electrical network, such as the detection of swells and sags, as well as the measurement of the first 31 harmonics. It describes the integration of the prototype at the hardware level and the design of the algorithms for its operation. Finally, the results obtained from the tests carried out with the device in operation are presented.
\end{abstract}

Power Quality, Embedded System, Harmonic Distorsión, Fast Fourier Transform

\section{Resumen}

El presente trabajo muestra el desarrollo de una plataforma, basada en un sistema embebido, para el monitoreo de disturbios presentes en la red eléctrica, como la detección de crestas y valles, además de la medición de los primeros 31 armónicos. Se describe la integración del prototipo a nivel hardware y el diseño de los algoritmos para su funcionamiento. Por último, se presentan los resultados obtenidos a partir de las pruebas realizadas con el dispositivo en funcionamiento.

Calidad de la Energía, Sistema Embebido, Distorsión Armónica, Transformada Rápida de Fourier

Citation: TURIJÁN-ALTAMIRANO, Salomón Noé, MUÑOZ-HERNÁNDEZ, Germán Ardul, CHÁVEZ-CANO, Omar and RODRÍGUEZ-GONZÁLEZ, Julio. Platform design for monitoring the quality of electrical energy. Journal of Computational Systems and ICTs. 2019, 5-15: 1-9.

\footnotetext{
* Correspondence to Author (email: noe.turijan@ gmail.com)

$\dagger$ Researcher contributing first author.
} 


\section{Introduction}

Electric power is used in different areas, at the domestic level it is used to operate household appliances, power luminaires, televisions, cell phone chargers, among others, and if we speak at an industrial level it is necessary to activate machines and equipment in workshops and laboratories, as well as to energize complete industrial processes, so we can realize how indispensable this resource is.

Being an input of such importance, it is desired to obtain the best use to optimize its consumption. A key point that must be taken into account is the quality of electrical energy, which refers to the amount of signal distortion, which ideally corresponds to a sine wave with constant amplitude, frequency and phase.

Part of the disturbances in the electrical signal are inherent to the distribution process from the power plant that is responsible for providing the resource, so in the design of the devices, equipment or machines a tolerance must be taken into account for these defects.

On the other hand, the phenomena that affect the quality of energy can also be caused or amplified by the way they work with it, since the use of electric machines with inductive loads and in general any non-linear load also tends to affect the supply Ironically, electronic technology, for the most part, has a non-linear behavior so that increasing the use of devices with these components increases the deformation of the power supply line.

Devices that operate on electric power have a certain sensitivity range to work with supply disturbances. When this limit is exceeded, the machines can begin to suffer alterations that many times may be imperceptible to the users but that with a long exposure affects the useful life of the device [1].

This series of disturbances has been studied over time, establishing a classification and the parameters that define each event, creating a regulation that will serve as a reference guide for the investigations carried out in this field [2].
The phenomena that alter the quality of energy can have a very short duration of time, so quantifying or even capturing them is a difficult process that could not be achieved with basic equipment.

This document addresses the design, implementation and programming of a platform for monitoring the quality of electrical energy based on the IEEE 1159-2009 standard and IEC 61000-4-30: 2015 to recognize the disturbances that they show up.

\section{Power quality}

To operate a device or process, it must be connected to an electrical supply that meets certain characteristics, depending on the region where it works. In Mexico, the Federal Electricity Commission is responsible for providing energy, consisting of a sine wave with a frequency of $60 \mathrm{~Hz}$ and an effective voltage of $127 \mathrm{~V}$ (Figure 1) for domestic use or $220 \mathrm{~V}, 440 \mathrm{~V}$, among others, for industrial use [3].
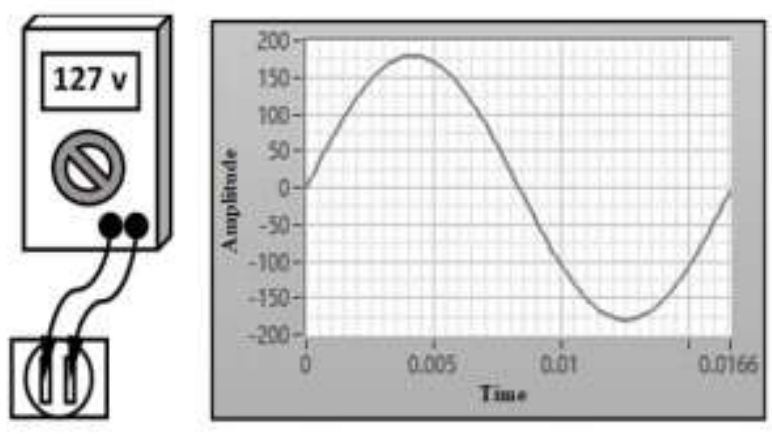

Figure 1 AC power supply

Source: Own elaboration

If these conditions are fulfilled, the devices may work, however, it is very likely that the actual electrical signal presents certain alterations that are difficult to perceive if it is measured with basic instruments such as a multimeter or an oscilloscope [4].

These phenomena will cause that the energy consumption is not efficient and, in some cases, will reduce the useful life of the machines. For these reasons, the study of energy quality has emerged, with the aim of establishing certain standards that can serve suppliers, users and manufacturers to measure these disturbances in order to try to reduce the impact they have [5]. 
Standard 61000-4-30 of the year 2015 of the International Electrotechnical Commission (IEC) defines the methods for measuring and interpreting results for power quality for alternating current power systems with a frequency of $50 \mathrm{~Hz}$ or $60 \mathrm{~Hz}$. The standard includes a classification of the main phenomena (table 1) as well as the duration and amplitude parameters to be able to identify them (table 2).

\begin{tabular}{|l|l|}
\hline $\begin{array}{l}\text { Conducted } \\
\text { phenomena of low } \\
\text { frequency }\end{array}$ & $\begin{array}{l}\text { Harmonics, interharmonics } \\
\text { Signals transmitted on the } \\
\text { network } \\
\text { Voltage fluctuations } \\
\text { Voltage gaps and interruptions } \\
\text { Voltage imbalance } \\
\text { Frequency variations } \\
\text { Low frequency induced voltage } \\
\text { CD component in AC network }\end{array}$ \\
\hline $\begin{array}{l}\text { Low frequency } \\
\text { radiated } \\
\text { phenomena }\end{array}$ & $\begin{array}{l}\text { Magnetic fields } \\
\text { Electric fields }\end{array}$ \\
\hline $\begin{array}{l}\text { High frequency } \\
\text { driven phenomena }\end{array}$ & $\begin{array}{l}\text { Induced voltages or currents of } \\
\text { continuous wave } \\
\text { Unidirectional Transients } \\
\text { Oscillatory transients }\end{array}$ \\
\hline $\begin{array}{l}\text { High frequency } \\
\text { radiated } \\
\text { phenomena }\end{array}$ & $\begin{array}{l}\text { Electric fields } \\
\text { Magnetic fields } \\
\text { Electromagnetic fields } \\
\text { Continuous waves } \\
\text { Transitory }\end{array}$ \\
\hline $\begin{array}{l}\text { Electrostatic } \\
\text { discharge } \\
\text { phenomena }\end{array}$ & - \\
\hline $\begin{array}{l}\text { Nuclear } \\
\text { electromagnetic } \\
\text { pulses }\end{array}$ & - \\
\hline
\end{tabular}

Table 1 Classification of the main phenomena that affect energy quality

Source: Adapted from IEEE 1159-2009
June 2019 Vol.5 No.15 1-9

\begin{tabular}{|c|c|c|c|}
\hline & Category & Duration & Magnitude \\
\hline 1. & $\begin{array}{l}\text { Transitory } \\
\text { 1.1. Impulsive } \\
\text { 1.1.1. Nanoseconds } \\
\text { 1.1.2. Microseconds } \\
\text { 1.1.3. Miliseconds } \\
\text { 1.2. Oscilatory } \\
\text { 1.2.1. Low frecuency } \\
\text { 1.2.2. Medium frecuency } \\
\text { 1.2.3. High frecuency }\end{array}$ & $\begin{array}{l}<50 \mathrm{~ns} \\
50 \mathrm{~ns}-1 \mathrm{~ms} \\
>1 \mathrm{~ms} \\
0.3-50 \mathrm{~ms} \\
20 \mathrm{us} \\
5 \mathrm{us}\end{array}$ & $\begin{array}{l}0-4 \mathrm{pu} \\
0-8 \mathrm{pu} \\
0-4 \mathrm{pu}\end{array}$ \\
\hline 2. & $\begin{array}{l}\text { Short-term rms variations } \\
\text { 2.1. Instant } \\
\text { 2.1.1. Sag } \\
\text { 2.1.2. Swell } \\
\text { 2.2. Momentary } \\
\text { 2.2.1. Interruptions } \\
\text { 2.2.2. Sag } \\
\text { 2.2.3. Swell } \\
\text { Temporary } \\
\text { 2.3.1. Interruptions } \\
\text { 2.3.2. Sag } \\
\text { 2.3.3. Swell } \\
\end{array}$ & $\begin{array}{l}0.5-30 \text { cycles } \\
0.5-30 \text { cycles } \\
0.5 \text { cycles }-3 \mathrm{~s} \\
30 \text { cycles }-3 \mathrm{~s} \\
30 \text { cycles }-3 \mathrm{~s} \\
>3 \mathrm{~s}-1 \mathrm{~min} \\
>3 \mathrm{~s}-1 \mathrm{~min} \\
>3 \mathrm{~s}-1 \mathrm{~min}\end{array}$ & $\begin{array}{l}0.1-0.9 \mathrm{pu} \\
1.1-1.8 \mathrm{pu} \\
<0.1 \mathrm{pu} \\
0.1-0.9 \mathrm{pu} \\
1.1-1.4 \mathrm{pu} \\
<0.1 \mathrm{pu} \\
0.1-0.9 \mathrm{pu} \\
1.1-1.2 \mathrm{pu}\end{array}$ \\
\hline 3. & \begin{tabular}{ll}
\multicolumn{2}{l}{ Long-term rms variations } \\
3.1. & Sustained Interruptions \\
3.2. & Voltaje Drops \\
3.3. & Overvoltages \\
3.4. & Current overload \\
\end{tabular} & $\begin{array}{l}>1 \mathrm{~min} \\
>1 \mathrm{~min} \\
>1 \mathrm{~min} \\
>1 \mathrm{~min}\end{array}$ & $\begin{array}{l}0.0 \mathrm{pu} \\
0.8-0.9 \mathrm{pu} \\
1.1-1.2 \mathrm{pu}\end{array}$ \\
\hline 4. & $\begin{array}{ll}\text { Imbalance } \\
4.1 . \quad \text { Voltaje } \\
4.2 . & \text { Current } \\
\end{array}$ & $\begin{array}{l}\text { Stable state } \\
\text { Stable state }\end{array}$ & $\begin{array}{l}0.5-2 \% \\
1.0-30 \% \\
\end{array}$ \\
\hline 5 . & \begin{tabular}{ll}
\multicolumn{2}{l}{ Waveform distortion } \\
5.1. & Offset $\mathrm{CD}$ \\
5.2. & Harmonics \\
5.3. & Interharmonics \\
5.4. & Notching \\
5.5. & Noise \\
\end{tabular} & $\begin{array}{l}\text { Stable state } \\
\text { Stable state } \\
\text { Stable state } \\
\text { Stable state } \\
\text { Stable state }\end{array}$ & $\begin{array}{l}0-0.1 \% \\
0-20 \% \\
0-2 \% \\
0-1 \%\end{array}$ \\
\hline 6. & Voltaje Fluctuations & Intermitent & $0.1-7 \%$ \\
\hline & Frecuency Variations & $<10 \mathrm{~s}$ & $\pm 0.1 \mathrm{~Hz}$ \\
\hline
\end{tabular}

Table 2 Disturbance Parameters

Source: Adapted from IEEE 1159-2009

Among the main disturbances are the crest (sags) and voltage valleys (swells), which are alterations in the RMS voltage level of the original signal over a period of half a cycle to 1 minute.

Another of the phenomena that occur are the harmonic signals, which are waves with an integer multiple frequency of the fundamental (Figure 2).

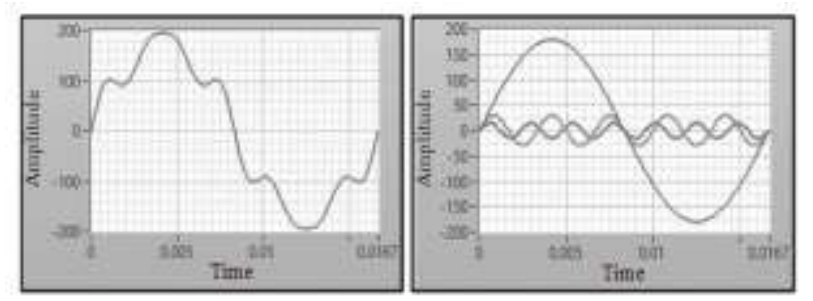

Figure 2 Distorted signal and its harmonic components Source: Own elaboration

Over the years, research has been conducted to build devices that can measure these defects. Among the main ones, the following are taken into consideration: 
In 2005 [4], a device for recording interruptions and voltage drops was developed to conduct studies of voltage wave quality. The information was sent and presented on the computer through a graphical interface.

In 2011 [6] the phenomena of voltage drops and rises are analyzed to design and implement a system with the ability to detect them using a computer and Matlab software for signal processing.

In 2015 [7] a disturbance acquisition and evaluation system was implemented, applied to the particular case of single-phase electrical systems based on the IEEE 1159 standard of the year 1995. It works with hardware and software of the National Instrumenta company using the application of LabVIEW to process the signals and create an interface on the computer to present the results.

From the previous investigations, progress can be observed in terms of research regarding the measurement of quality of electrical energy. The proposal of this project covers the design and implementation of a platform capable of detecting the phenomena of sag, swell and harmonics, present in an electrical network.

Unlike the projects described above, this platform will not depend on a computer to process the signals, instead embedded systems are used to create an instrument that is portable, with the option of being able to view the event report. registered through visual indicators.

\section{Platform design and integration}

The following scheme (Figure 3) shows the proposed system architecture with the stages that are required for its operation. The platform will cover analog-to-digital conversion, signal processing and event history display. It is worth mentioning that the conditioning of the input signal must be carried out by external hardware.

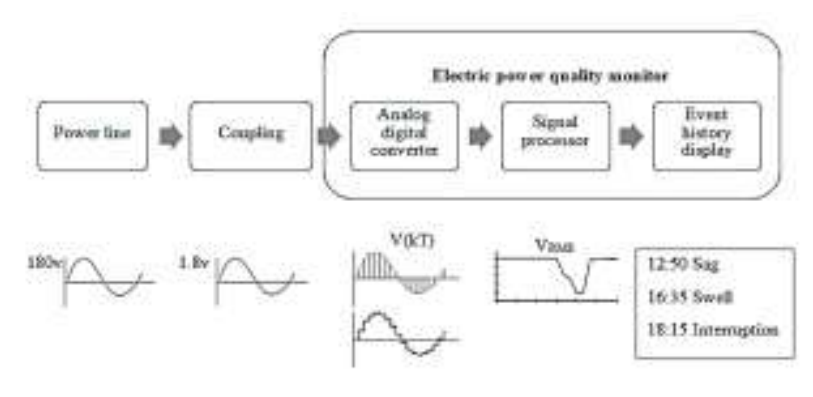

Figure 3 Block diagram of the platform for measuring the quality of electrical energy

Source: Own elaboration

For the implementation of the project, the ASSERTA [8] development card, from the INTESC company, is used, which contains the necessary components for signal acquisition and processing.

At its core it has a Spartan 6 XC6SLX16 FPGA (Figure 4) that can be configured through hardware description language (VHDL).

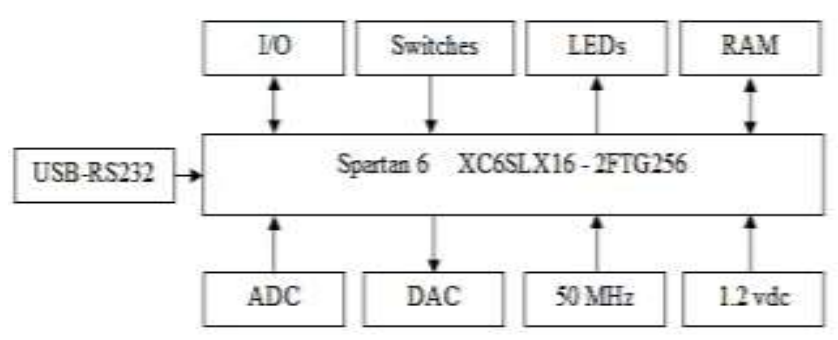

Figure 4 Block diagram Asserta card Source: intesc.mx

The Analog Devices AD7265 AnalogDigital Converter with the following specifications is used for the data acquisition stage [9]:

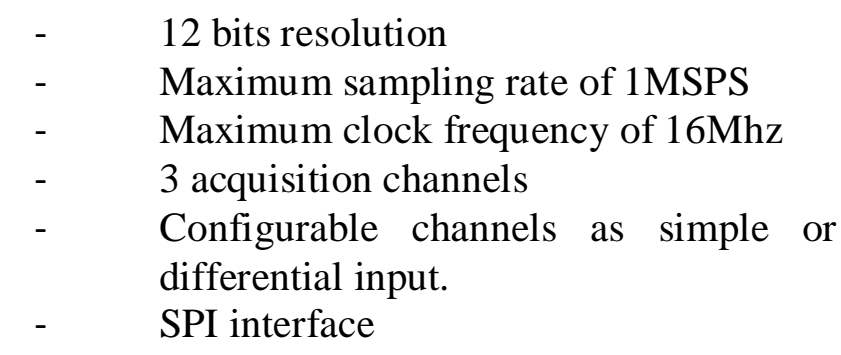

The sampling rate is defined from the frequency of the upper harmonic to be measured, in this case it is number 31 , with a frequency of $1,860 \mathrm{~Hz}$ taking as the fundamental frequency, that is, the first harmonic of $60 \mathrm{~Hz}$ corresponding to the power supply. 
According to the sampling theorem [10], a sampling frequency greater than twice the frequency to be quantified is required, so a sampling rate greater than $3,720 \mathrm{~Hz}$ is required to avoid the splicing effect (aliasing).

The frequency selected for sampling is $3,840 \mathrm{~Hz}$ which allows to represent a sine wave cycle with 64 samples.

Through the hardware description language, the module is developed in the fpga to deal with SPI communication with the ADC, based on the 50Mhz oscillator frequency.
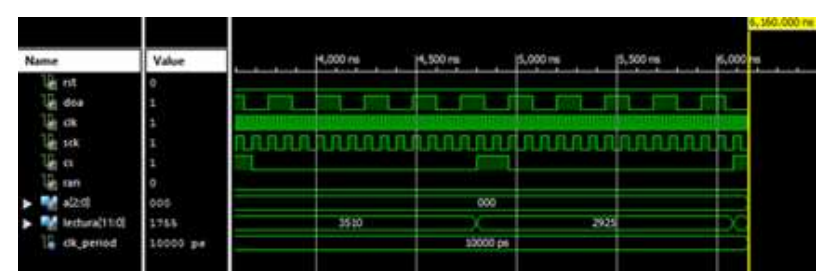

Figure 5 SPI communication for the ADC Source: Own elaboration

For the connection of the analog inputs, the Asserta card has an SMA port for each channel. Through an SMA to BNC adapter it is possible to connect dimmed probes as shown in Figure 6.

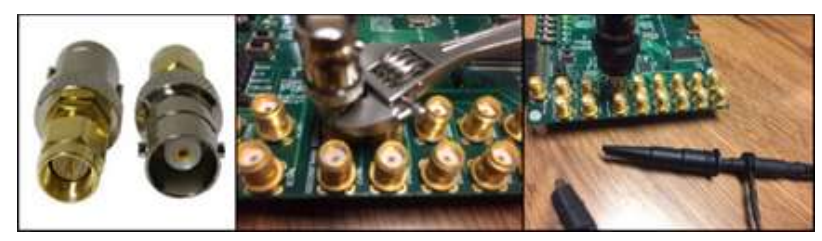

Figure 6 SMA to BNC adapter

Source: Own elaboration

The samples obtained describe the amplitude of the wave over time. The algorithm is used to obtain the RMS Quadratic Mean Root value [4] to get the direct current equivalent of the original alternating current signal.

$V_{R M S}=\sqrt{\frac{1}{N} * \sum_{i=1}^{N} v_{i}^{2}}$

Figure 7 shows the flow chart of the algorithm to obtain the RMS value.

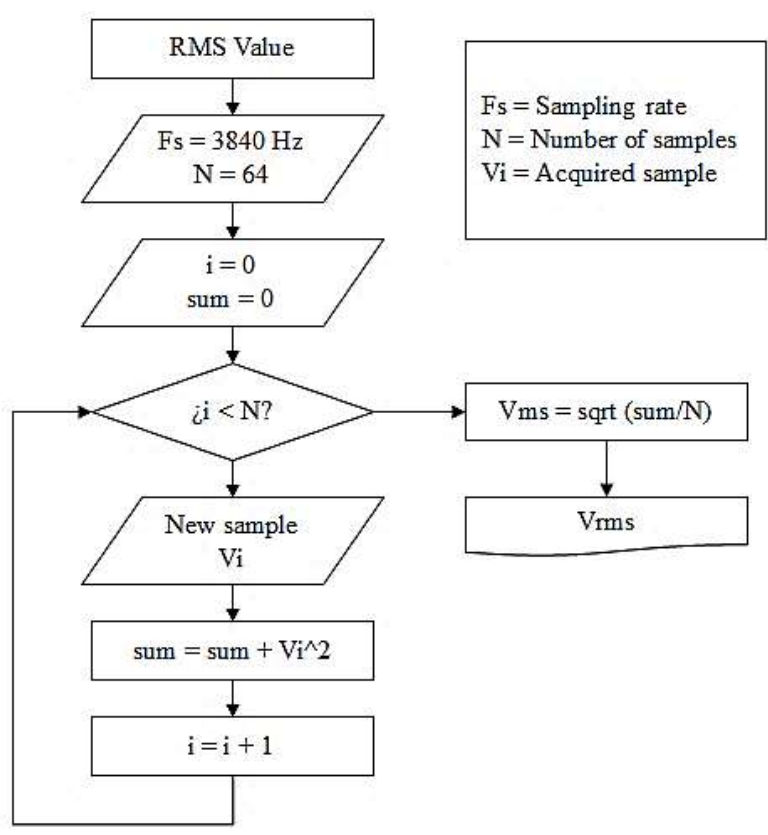

Figure 7 Flowchart to obtain RMS value Source: Own elaboration

Figure 8 shows the simulation of a voltage sag in the original signal and with the rms value.

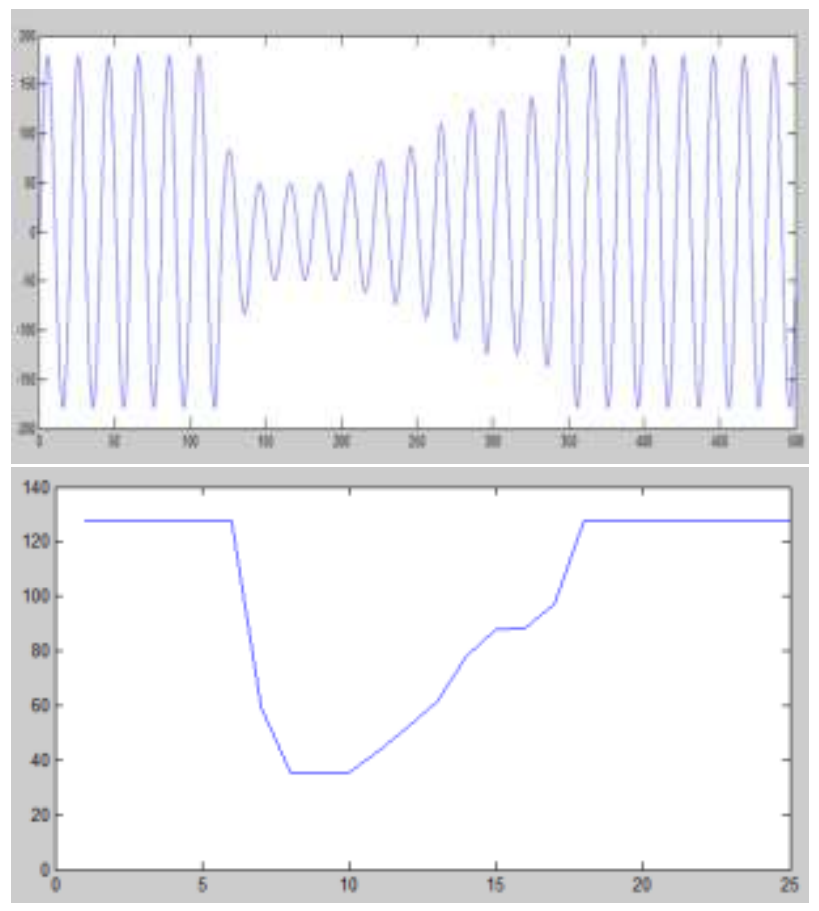

Figure 8 Voltage sag

Source: Own elaboration

From the acquisition and conversion of the signal, defects in the quality of the supply can be determined, detecting the variations and their duration as described in the standard [11].

The flowchart to detect disturbances is shown in Figure 9, in addition to taking the initial and final time to generate a detected event tag.

TURIJÁN-ALTAMIRANO, Salomón Noé, MUÑOZ-HERNÁNDEZ, Germán Ardul, CHÁVEZ-CANO, Omar and RODRÍGUEZGONZÁLEZ, Julio. Platform design for monitoring the quality of electrical energy. Journal of Computational Systems and ICTs. 2019. 


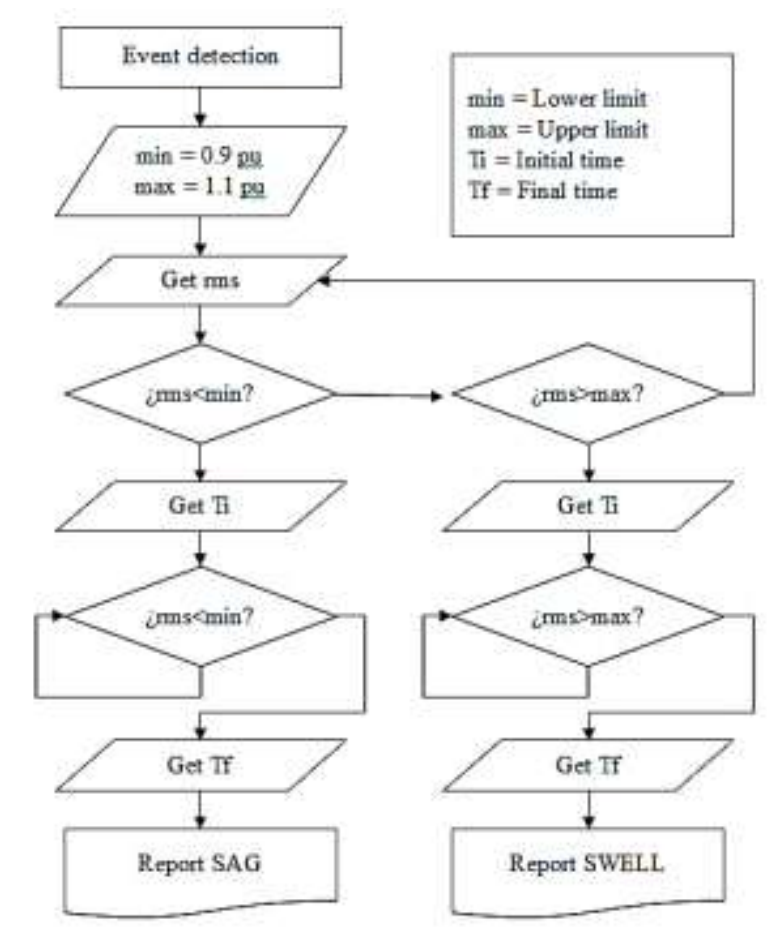

Figure 9 Flowchart for event detection Source: Own elaboration

The first tests are programmed in the development card to work in a basic mode, allowing to show the time at which the last event occurs and activating a light at the time it occurs, as shown in Figure 10.

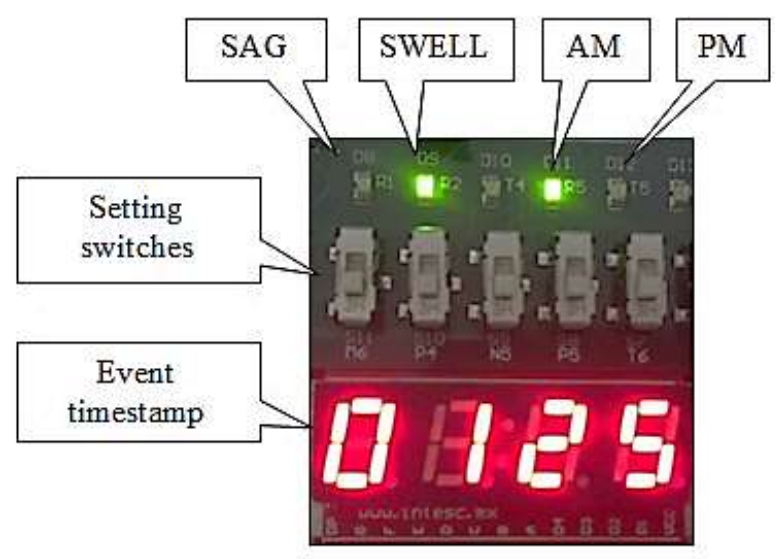

Figure 10 Basic mode for disturbance detection Source: Own elaboration

Harmonic distortion requires analysis by means of the Fast Fourier Transform [12], which allows to obtain the frequencies that make up the original signal [13]. The algorithm used is shown below:

$$
\begin{aligned}
& Y(k)=\sum_{n=0}^{N-1} v(n) W_{N}^{k n} \\
& W_{N}=e^{-i 2 \pi / N}
\end{aligned}
$$

In Figure 11 you can see the flow chart to calculate the FFT of the original signal and thus obtain the harmonics.

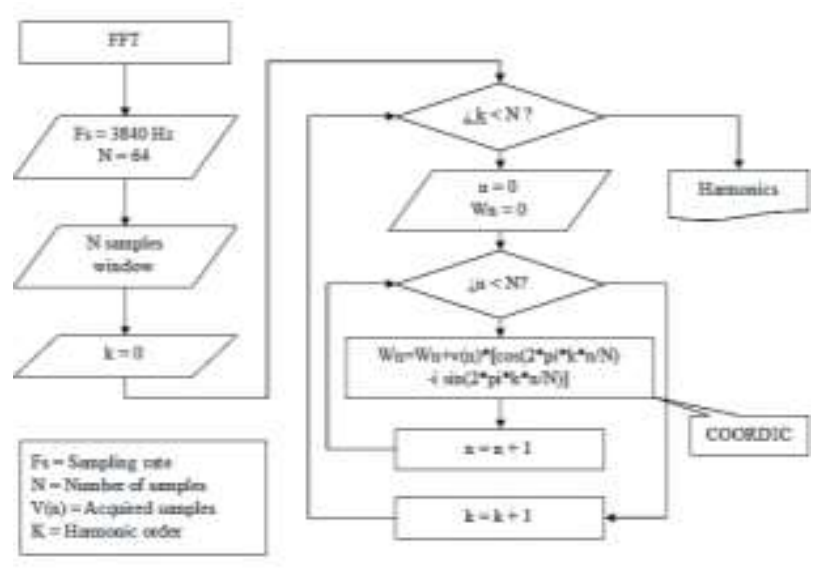

Figure 11 Flowchart to obtain harmonics Source: Own elaboration

The simulation, with the amplitudes of the harmonics of interest, is shown in Figure 12, where the greatest contribution of the fundamental frequency of $60 \mathrm{~Hz}$ is observed:

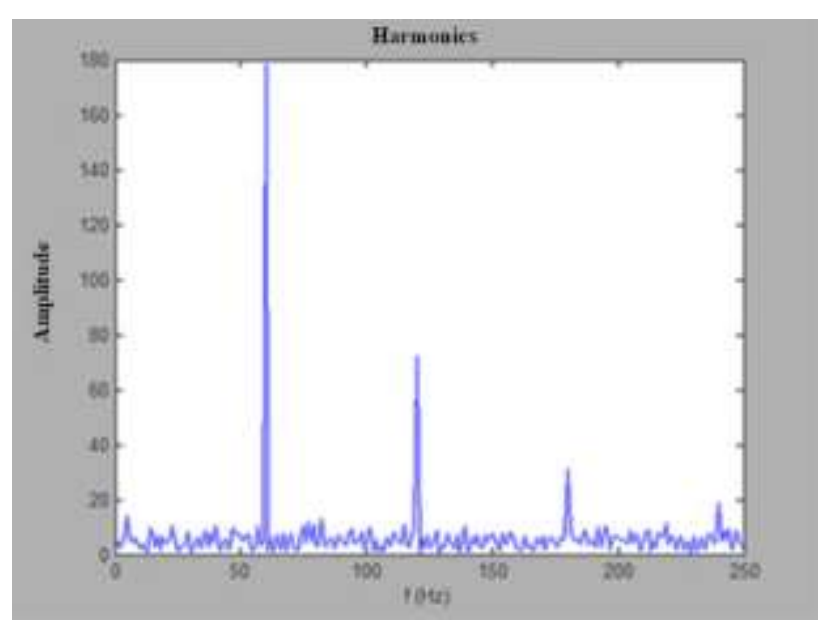

Figure 12 Result of FFT Source: Own elaboration

To display the final information to the user, the results are sent to a screen capable of displaying graphics, text and quantities for better representation. Figure 13 and 14 how the screen placement and some test graphics. 


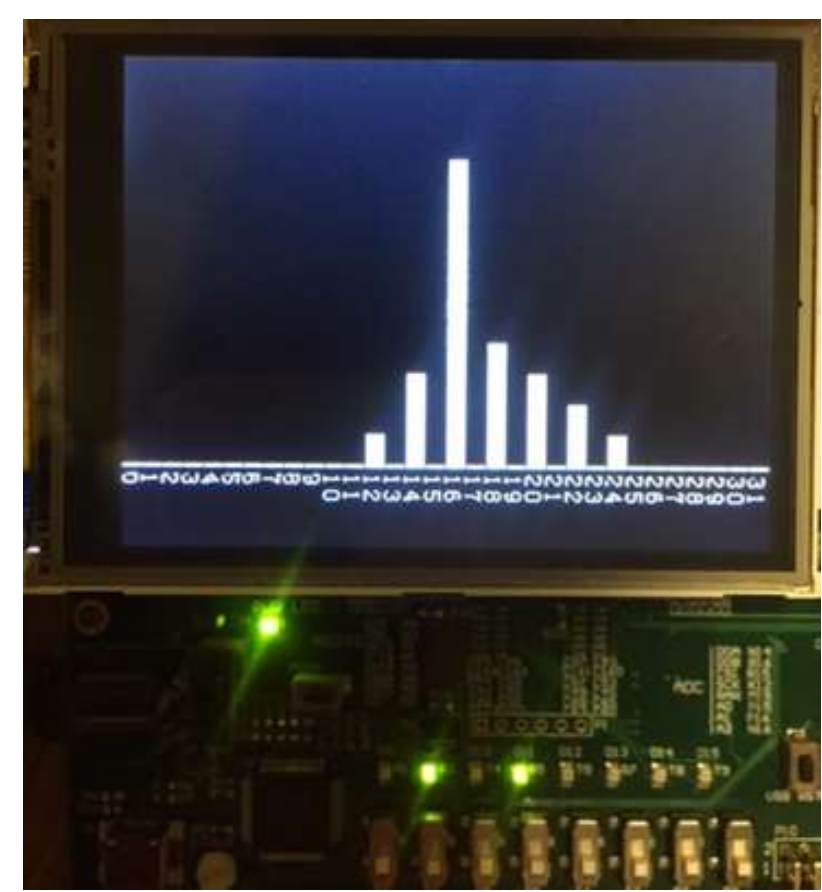

Figure 13 Display for information display Source: Own elaboration

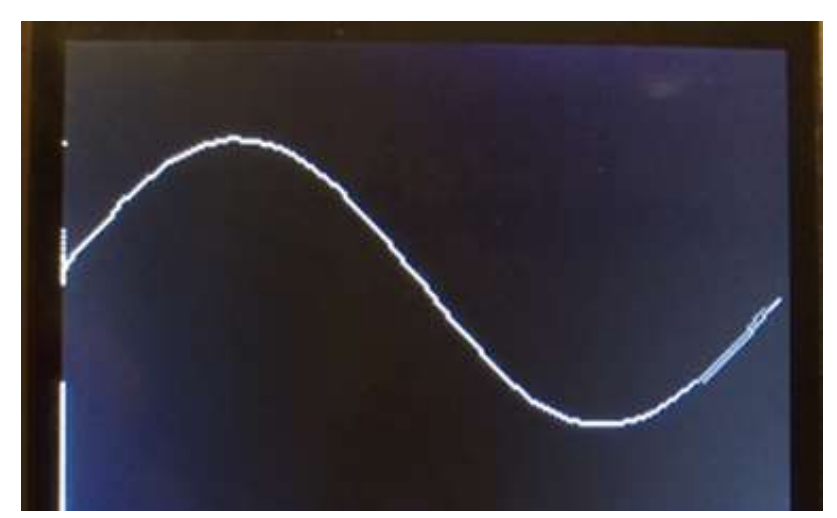

Figure 14 Input Wave Graph

Source: Own elaboration

\section{Tests and results}

After the design and simulation of the algorithms, they were transferred to the ASSERTA development card for testing physical signals.

To compare the results, a TEKTRONIX digital oscilloscope model TBS 1102B-EDU was used.

Figure 15 shows the result of obtaining the RMS value of an input signal. When the value is decreased, the time of the event is marked and displayed as a list on the right side of the screen so that the user has a history of events that have occurred.

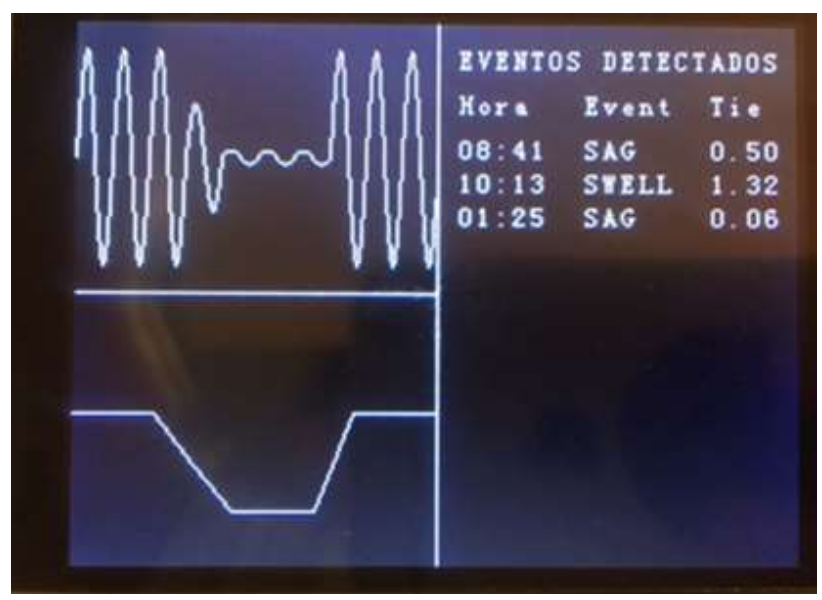

Figure 15 Event detection and deployment with the monitoring platform

Source: Own elaboration

The second resource is the magnitude graph for each of the 31 harmonics. Figure 16 shows a capture of the harmonics obtained, where the user can identify their presence.

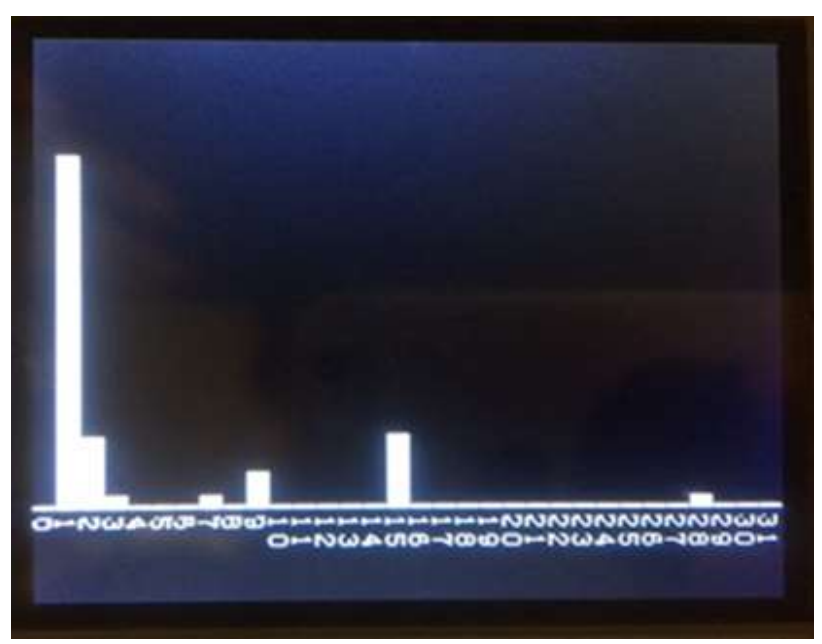

Figure 16 Harmonic measurement results Source: Own elaboration

Finally, the deployment of harmonics measured now in a table format is carried out so that the value that each one contributes to the distortion of the original signal can be analyzed in detail.

Figure 17 shows the harmonic measurement result, displaying the magnitude and frequency to which each one corresponds. 


\begin{tabular}{|c|c|c|c|c|}
\hline 0 & $\mathrm{Kz}$ & 0.00 & $960 \mathrm{Kz}$ & 0.00 \\
\hline 60 & $\mathrm{Kz}$ & 0.98 & $1020 \mathrm{Kz}$ & 0.00 \\
\hline 120 & $\mathrm{Kz}$ & 0.00 & $1080 \mathrm{Kz}$ & 0. 42 \\
\hline 180 & $\mathrm{Kz}$ & 0.00 & $1140 \mathrm{Kz}$ & 0.00 \\
\hline 240 & $\mathrm{Kz}$ & 0.00 & $1200 \mathrm{Kz}$ & 0.31 \\
\hline 300 & $\mathrm{Kz}$ & 0.00 & $1280 \mathrm{Kz}$ & 0.00 \\
\hline 360 & $\mathrm{Kz}$ & 0.00 & $1320 \mathrm{Kz}$ & 0.19 \\
\hline 420 & $\mathrm{~Hz}$ & 0.00 & $1380 \mathrm{Kz}$ & 0.00 \\
\hline 480 & $\mathrm{Kz}$ & 0.00 & $1440 \mathrm{Kz}$ & 0.15 \\
\hline 540 & $\mathbf{K z}$ & 0.00 & $1500 \mathrm{Kz}$ & 0.00 \\
\hline 600 & $\mathrm{Kz}$ & 0.00 & $1560 \mathrm{Kz}$ & 0.00 \\
\hline 660 & $\mathrm{Kz}$ & 0.00 & $1620 \mathrm{Kz}$ & 0.00 \\
\hline 720 & $\mathrm{Kz}$ & 0.12 & $1680 \mathrm{Kz}$ & 0.00 \\
\hline 780 & $\mathrm{Kz}$ & 0.00 & $1740 \mathrm{Kz}$ & 0.00 \\
\hline 840 & $\mathrm{Kz}$ & 0.34 & $1800 \mathrm{Kz}$ & 0.00 \\
\hline 900 & $\mathrm{Kz}$ & 0.00 & $1860 \mathrm{Kz}$ & 0.00 \\
\hline
\end{tabular}

Figure 17 Harmonics Table

Source: Own elaboration

\section{Conclusions}

The implementation of the platform for monitoring the quality of electrical energy covered the design and programming of algorithms in an embedded system for the detection of peak (swell) and voltage valleys (sag), in addition to measuring 31 harmonics from the fundamental frequency provided by the electricity supply, according to current regulations.

With the platform for detection and monitoring of electrical energy quality, the requirements of the standard regarding its three stages are met:

The basic event detection mode with a time stamp is incorporated.

A visual indicator is incorporated to show a history of events, the frequency spectrum for the first 31 harmonics, as well as a table with the respective magnitudes.

Communication is enabled for sending data to external hardware for possible connection to a graphical interface executed on a computer.

\section{Acknowledgments}

The authors thank the Division of Postgraduate Studies and Research of the Technological Institute of Puebla / Technological National of Mexico for their collaboration and provision of laboratories and equipment for the development of research and the National Council of Science and Technology for the financial support provided.

\section{References}

[1] IEEE Power \& Energy Society, IEEE Recommended Practice for Monitoring Electric Power Quality, New York: IEEE, 2009.

[2] S. Chattopadhyay, M. Mitra y S. Sengupta, Electric Power Quality, New York: Springer, 2011.

[3] R. Jiménez y J. Cerro, «Perspectiva de calidad de la energía eléctrica y su importancia en México,» Área de Normalización, Departamento de Compatibilidad Electromagnética.

[4] M. Á. Ángel Silva y G. Ordóñez Plata, «Calidad de la Energía Eléctrica: Diseño y Construcción de un Prototipo como Alternativa para la Monitorización de Interruptions y Caídas de Tensión,» Revista de la Facultad de Ingenierías Fisicomecánicas, vol. 4, no 2, pp. 75-84, 2005.

[5] G. M. Robledo Leal, «Calidad de la Energía Eléctrica: Camino a la Normalización,» 2008.

[6] W. L. Rodriguez Galvis y M. I. Useche Gamboa, Diseño e Implementación de un Equipo Analizador de Calidad de Energía Eléctrica, Bucaramanga, 2010.

[7] J. L. Díaz Rodríguez, L. D. Pabón Fernández y J. L. Contreras Peña, «Low-cost platform for the evaluation of single phase electromagnetic phenomena of power quality according to the IEEE 1159 standard,» pp. 119129, 2015.

[8] INTESC electronics \& embedded, «www.intesc.mx,» 2019. [En línea]. Available: https://www.intesc.mx/productos/asserta/.

[Último acceso: 7 Junio 2019].

[9] ANALOG DEVICES, AD 7265. Differential/Single-Ended Input, Dual 1 MSPS, 12-Bit, 3-Channel SAR ADC, Norwood USA, 2018.

[10] A. V. Oppenheim, R. W. Schafer y J. R. Buck, Tratamiento de Señales en Tiempo Discreto, Prentice Hall. 
[11] Y. Biletskiy, S. Nanacekivell, L. Chang y S. Riming, «An FPGA-based Power Quality Monitoring and Event Identifier,» 2017.

[12] A. Ambardar, Procesamiento de Señales Analógicas y Digitales, 2002.

[13] Z. Oubrahim, «On Electric Grid Power Quality Monitoring using Parametric Signal Processing Techniques,» 2017. 